American Journal of Pharmaceutical Education 2019; 83 (3) Article 6592.

\title{
RESEARCH
}

\section{A Global Comparison of Internationalization Support Characteristics Available on College of Pharmacy Websites}

\author{
Ines Nunes-da-Cunha, PharmD, MSc, ${ }^{\mathrm{a}}$ Fernando Martinez Martinez, PhD, PharmD, ${ }^{\mathrm{a}}$ \\ Fernando Fernandez-Llimos, PhD, PharmD, $\mathrm{MBA}^{\mathrm{b}}$ \\ ${ }^{a}$ Faculty of Pharmacy, University of Granada, Granada, Spain \\ ${ }^{\mathrm{b}}$ Institute for Medicines Research (iMed.ULisboa), Faculty of Pharmacy, University of Lisbon, Lisbon, Portugal \\ Submitted June 16, 2017; accepted September 20, 2017; published April 2019.
}

Objective. To compare the information regarding entry-level pharmacy degree programs available on college websites worldwide from the perspective of international students.

Methods. Data on pharmacy colleges and schools were extracted from the Official World List of Pharmacy Schools on the International Pharmaceutical Federation (FIP) website. The website of each pharmacy college was accessed and the content was analyzed. A scoring method was created to compare the websites.

Results. Of the 1839 pharmacy colleges listed worldwide, 246 had no website. Approximately half of pharmacy colleges with websites did not have a complete English version of their site. Academic information considered important by students, including the course syllabi, admission requirements, program costs, and a faculty directory, was not available on $73 \%, 44 \%, 65 \%$ and $43 \%$ of the websites, respectively. The websites of pharmacy colleges in Oceania, North America, and Europe provided the best information for international students, with these regions scoring an average of 9.2, 8.8, and 6.7, respectively out of 12 points. In comparison, pharmacy colleges in Central Asia and East and Southeast Asia scored an average of only 0.2 and 1.5 points, respectively.

Conclusion. There are still a high proportion of global colleges of pharmacy without websites. Also, the quality of pharmacy colleges' websites is unevenly distributed around the world. To fulfill the information needs of international students, pharmacy colleges should provide an English version of the website and include at least a complete syllabus of all the courses, financial information (costs and grants), a complete faculty directory, and all the administrative requirements for application and enrollment.

Keywords: websites, globalization, international students, pharmacy colleges, higher education

\section{INTRODUCTION}

The global rise of the internet has increased the number of websites that are used as sources of information. Many Universities have followed this evolution by creating websites that give prospective students their first impressions of the schools. ${ }^{1-3}$ Universities and colleges now use websites as highly influential recruitment tools. ${ }^{4-6}$ These university websites provide information about the schools' courses, educational programs, and online learning facilities and assignments. ${ }^{7}$ Students are mainly interested in study plans, timetables, and examination grades. Prospective stu-

Corresponding Author: Fernando Fernandez-Llimos, Department of Social Pharmacy, Faculdade de Farmacia, Universidade de Lisboa, Avda. Prof. Gama Pinto, 1649-019 Lisbon, Portugal. Tel. +351 217946400. E-mail: f-llimos@ff. ul.pt dents are interested mainly in study plans, facilities, building locations, registration information, and admission requirements. ${ }^{8}$

Previous literature has demonstrated the importance of university websites in the process of selecting a college. Prospective students trust information provided on a college website and will use this information to help them decide whether to apply to that college. Majors and tuition, followed by ranking, size and location, were the most commonly searched information items on college websites. ${ }^{9}$

The 2010 E-Expectations Report indicated that one in four students reported removing a school from their prospective list after a bad experience with that school's website, and $92 \%$ reported that "they would be disappointed with a school or remove it entirely from their list if they didn't find the information they needed on 


\section{American Journal of Pharmaceutical Education 2019; 83 (3) Article 6592.}

the school's Web site."2 A list of academic programs or degrees and academic program details were the two most valued types of content $(28.3 \%$ and $18.6 \%$ of the students, respectively). ${ }^{2}$ In the 2014 E-Expectations Report, prospective students $(77 \%)$ and their parents $(69 \%)$ rated college websites as the most influential resource when searching for a college. ${ }^{6}$ Schimmel and colleagues found that $94 \%$ of students examined the website before considering a school, and that the website's content was important in their decision-making process of which institution to attend. ${ }^{10}$ Students indicated that information about programs, course availability, location, and accreditations were the most important aspects of schools' websites, and that this information should be accessible from the homepage. ${ }^{10}$

Over the past 30 years, internationalization in higher education has increased ${ }^{11,12}$ and can be assessed by the institution's capacity to attract students who want to study abroad. ${ }^{13-15}$ The main reasons for the internationalization of institutions of higher education include improving student preparedness, internationalizing the curriculum, and enhancing the international profile of the institution. ${ }^{16,17}$ University websites also were the primary source of information about these institutions for international students. ${ }^{18}$ Students' experiences with university websites was reported as one of the mostinfluential factors in their decision to apply to a particular university. ${ }^{19}$ Noel-Levitz reported that the top five items searched on college websites by prospective international students were academic programs/majors, cost, scholarship information, financial aid, and admissions information. ${ }^{19}$ In addition, university websites act as a source of information for international students throughout their study abroad experience. ${ }^{20}$

Pharmacy education is not an exception in the internationalization of higher education, and pharmacy students have demonstrated interest in having international educational experiences. ${ }^{21}$ Thus, the purpose of this study was to compare information about entry-level pharmacy degree programs available on college websites from the perspective of international students.

\section{METHODS}

Institutions providing pharmacy education have different designations around the world (ie, colleges, schools, faculties). In this study, we used the term "colleges" to refer to all such higher-education institutions. Information about all of the colleges of pharmacy in the world was collected from the Official World List of Pharmacy Schools available on the website of the International Pharmaceutical Federation (FIP). ${ }^{22}$ Duplicate records and nonapplicable data from colleges that did not provide entry-level degrees for pharmacy were removed from the list.

By means of a Google search, the existence of a pharmacy college website for each college was investigated. Following previously published standards, a categorical web content analysis, including textual and visual contents whether in plain text or embedded in other files (eg, PDFs, movies), was performed. ${ }^{23-25}$ With this content analysis, a systematic qualitative and quantitative evaluation of the information provided on each website was completed. ${ }^{24}$ Data regarding which language(s) the website was in, what information was available on the site (eg, course syllabi), and the quality of the information available were collected from each college website in 2014. A website was considered to contain all syllabi if no more than five course syllabi were unavailable. Additional information about the colleges and their positions in ranking lists was obtained from the Academic Ranking of World Universities 2015. ${ }^{26}$ A content analysis of websites with content written in English, Spanish, French, Portuguese, Italian, or German was performed. Next, the websites were grouped according to the world region in which they were located. ${ }^{27}$

To compare websites quantitatively, a scoring method was created. Based on the content valued by students in previous studies, we assigned one point to each of the following items of information available on the website: degree granted, credits/hours required for the degree, the head of the college, faculty directory, admission requirements, tuition, pharmacy careers, professional competencies and outcomes, and curriculum information. Syllabi, when on the website, were scored according to quality, with one point for websites that were weak and only had partial syllabi available, and two points for websites that had complete and "rich" syllabi. A complete and rich syllabus was defined as one that, in addition to a description of course content, provided information about course goals (competencies) and objectives (skills, knowledge and attitudes that students need to acquire), units/time required and prerequisites/co-requisites, how to contact instructors, learning environment (facilities and teaching methods, required and recommended texts, and materials and attire), time schedule/course plan, assessment methods, technical classroom, and college policy information. ${ }^{28}$ If the website also had the information available in a foreign language, we assigned one extra point. The maximum (ie, best) score possible for a college was 12 points.

For each country with pharmacy colleges, we collected the following information: whether the country belonged to the $\mathrm{G} 20,{ }^{29}$ whether the country belonged to the Organization for Economic Co-operation and 


\section{American Journal of Pharmaceutical Education 2019; 83 (3) Article 6592.}

Development (OECD), ${ }^{30}$ the region of the world where the country was located, ${ }^{27}$ the total area of the country, ${ }^{27}$ its population, ${ }^{27}$ whether the country's official language was English, ${ }^{27}$ the number of internet users, ${ }^{27}$ the number of mobile cellular telephone subscribers, ${ }^{27}$ the number of pharmacists in the country, ${ }^{31}$ 2012 Human Development Index (HDI) value, ${ }^{32} 2012$ HDI rank, ${ }^{32} 2012$ Gross National Income (GNI) per capita, ${ }^{32}$ and 2015-2013 population with at least a secondary education. ${ }^{32}$

Website scores were compared using a $t$ test for dichotomous factors and an ANOVA with Bonferroni posthoc polychotomous analysis. For all analyses, a level of $5 \%$ was considered significant. The data were analyzed using SPSS, version 20 (IBM, Armonk, NY).

\section{RESULTS}

We extracted data on 1,839 pharmacy colleges from the FIP Official World List of Pharmacy Schools. ${ }^{22}$ The colleges of pharmacy were distributed in the following global regions ${ }^{27}$ : 117 in Africa, 19 in Central Asia, 23 in Central America, 282 in East and Southeast Asia, 211 in Europe, 101 in the Middle East, 161 in North America, 19 in Oceania, 329 in South America, and 577 in South Asia.

No website was found for 246 (13.4\%) pharmacy colleges. Of the 1,593 colleges with websites, $51.3 \%$ $(n=817)$ had a website that was written entirely in English, $15.2 \%(n=242)$ had a website that was only partially written in English, and $33.5 \%(n=534)$ had a website written entirely in a language other than English. Five pharmacy colleges in countries where English was a co-official language had no English version of the website (three colleges in Cameroon, one in Canada, and one in Sudan). Of the 949 colleges from countries with official and co-official languages other than English, 529 (55.7\%) had no English version of their website, $239(25.2 \%)$ had a partial translation of their website content into English, and $181(19.1 \%)$ had a complete version of their website in English. Egypt and Greece had the highest proportion of pharmacy college websites translated into English, with 15 of 21 Egyptian colleges and all four Greek colleges having English versions. In contrast, only one of the 252 Brazilian colleges and seven of the 99 Chinese colleges had English versions of their website content. A total of 1,466 (92.0\%) colleges had a website in English, French, German, Italian, Portuguese or Spanish and, subsequently, undergone a web content analysis (Table 1).

The mean website score of the 1,593 colleges of pharmacy with websites was 4.98 and SD (3.3) on a scale of 0 to 12 . Three hundred three $(19.0 \%)$ colleges scored zero points, while eight colleges scored the maximum 12 points. While Oceania, North America, and Central
America had no colleges scoring zero, Central Asia and East and Southeast Asia had $94.1 \%$ and $72.8 \%$, respectively, of colleges scoring zero (Figure 1). A significant difference among the scores of different global regions was noted as shown in Table $2(p<.001)$. Significant associations or correlations also were found for website scores and the majority of socioeconomic variables, but not with the number of pharmacists per 10,000 inhabitants (Table 3).

\section{DISCUSSION}

The purpose of this study was to compare the internationalization of pharmacy college websites by analyzing information available on the websites. We found Europe, North America, and Oceania as the global regions with pharmacy college websites that provided the most information for international students. Most higher-education institutions emphasized the importance of internationalization. ${ }^{16,33}$ According to the International Association of Universities (IAU) $4^{\text {th }}$ Global Survey, academic institutions in Asia, the Pacific, and North America are most likely to have quantitative international student recruitment targets. ${ }^{33}$ However, in our study, the websites of pharmacy colleges located in Asian regions had lower scores, going against the intention of internationalization. On the other hand, Europe, North America, and Oceania are the global regions with pharmacy colleges that seem to be better-prepared to receive international students, though Europe obtained the largest score range in our study.

To attract international students, university websites must have clear navigation, ${ }^{18}$ take multicultural differences into account, ${ }^{34}$ and make an English version of the entire website available online. ${ }^{35}$ Despite that the majority of higher-education institutions seem to acknowledge the importance of internationalization, ${ }^{16,33}$ our study found that while most $(86.6 \%)$ pharmacy colleges had websites, $33.5 \%$ of the sites were not in English and $15.2 \%$ were only partially translated into English. The lack of an English version of their pharmacy college websites was even more unusual in three of the countries where English was a co-official language (ie, Cameroon, Canada, and Sudan). Also surprising, two countries that are involved in major development increase rates namely, Brazil and China, had an extremely low proportion of colleges with English-version websites. As a basic prerequisite for making pharmacy college websites accessible to international students, further efforts are needed to create English versions of these websites as English is considered the academic lingua franca. ${ }^{36}$

We found that the information available on pharmacy college websites was not always current, complete, 
American Journal of Pharmaceutical Education 2019; 83 (3) Article 6592.

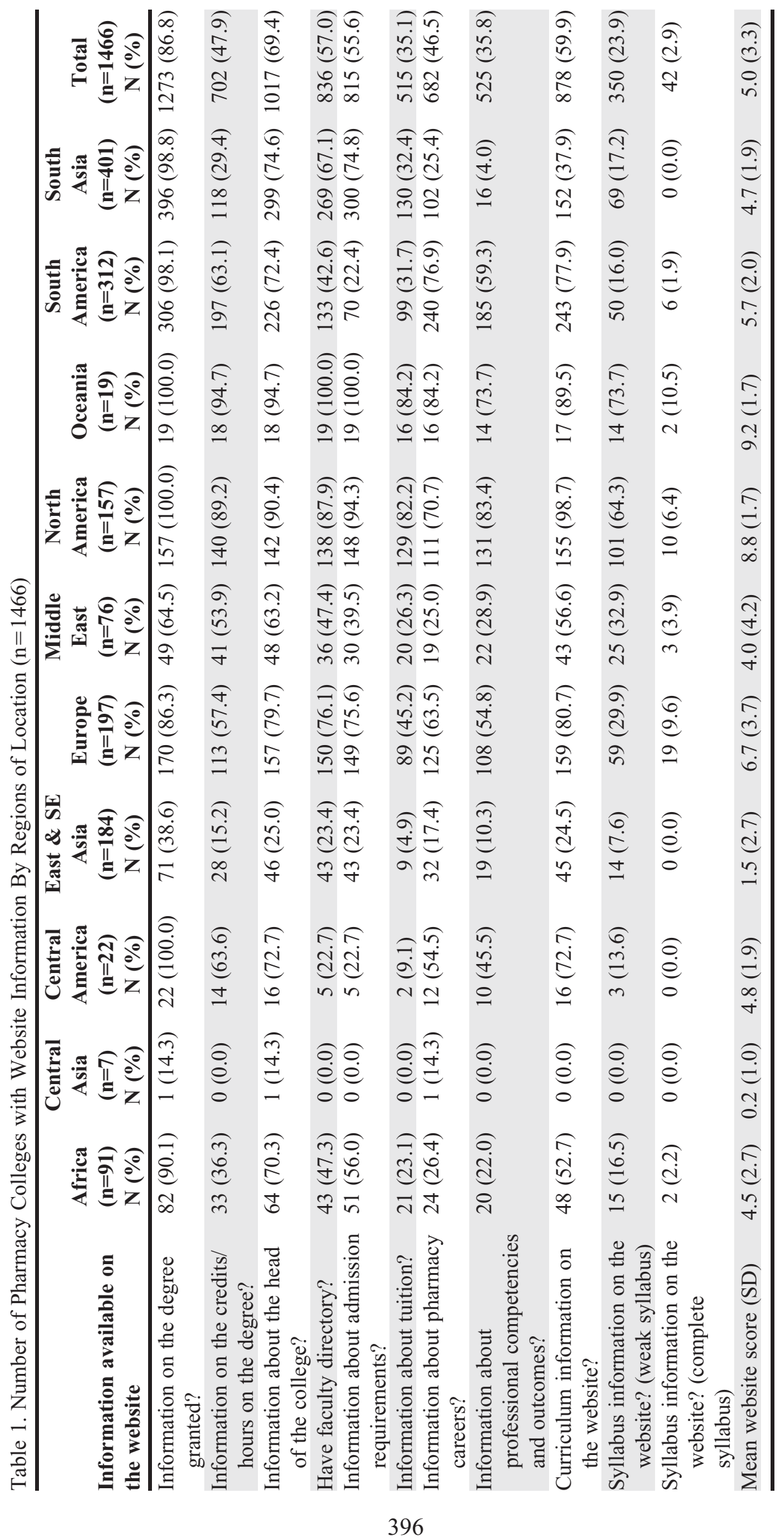


American Journal of Pharmaceutical Education 2019; 83 (3) Article 6592.

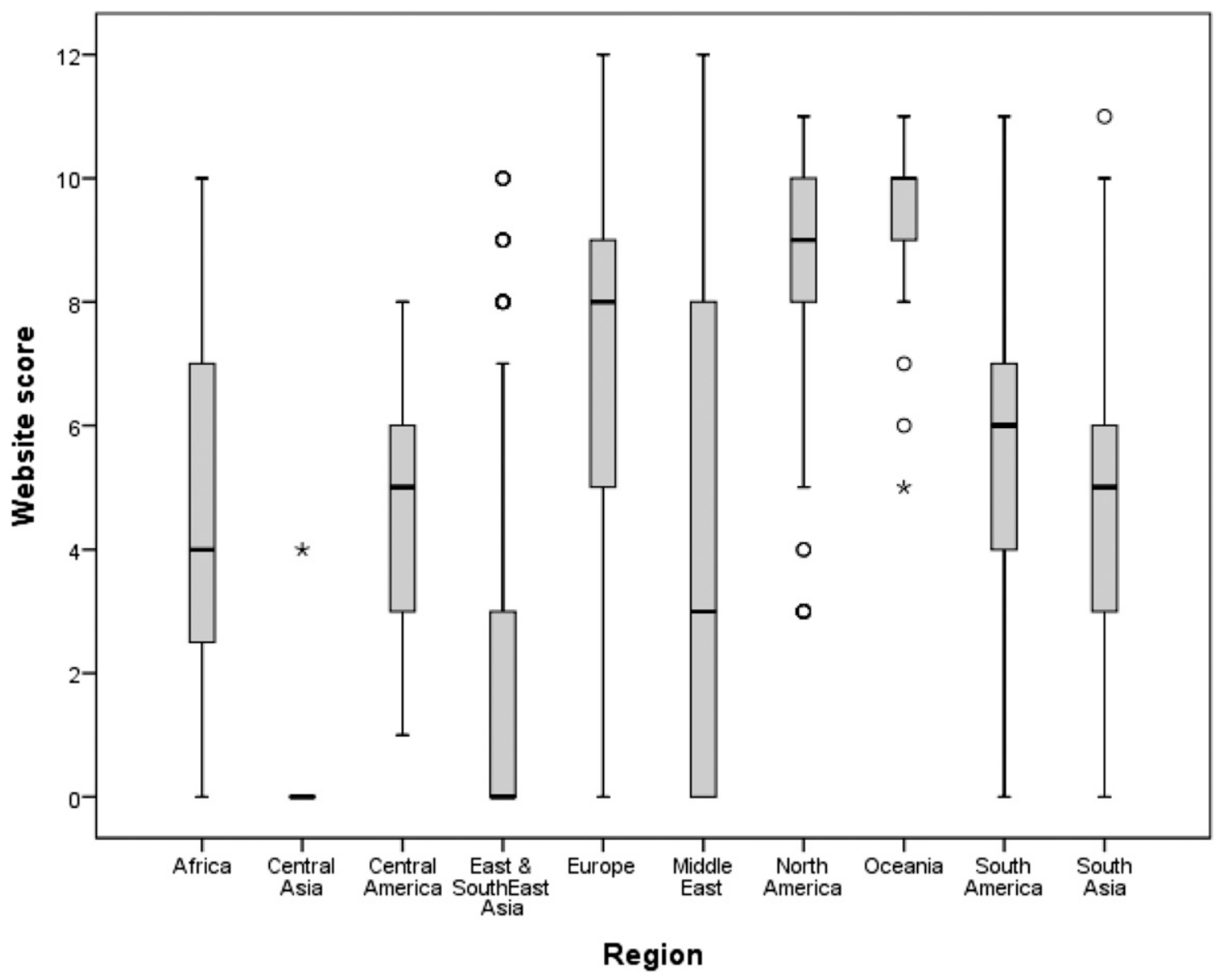

Figure 1. Box-plot of Quality Scores of Pharmacy College Websites by Regions of the World. The presence of 12 information elements was evaluated. The maximum (ie, best) score possible for a college was 12 points

or accurate. As corroborated by previous studies, many of the pharmacy college websites were not well organized, making it difficult to search for information. ${ }^{34}$ In a study by Meyer and Jones, prospective students reported that they needed information such as lists of degree programs, admission information, program requirements, and costs, and lists of faculty and syllabi from pharmacy college websites, and that this information should be easily accessible. According to the authors, this is the "information that helps the student function as a student." ${ }^{34}$ In our study, admission requirements, program costs, and faculty directories were available in $55.6 \%, 35.1 \%$, and $57.0 \%$ of pharmacy college websites, respectively. Approximately $73 \%$ of the 1,466 colleges of pharmacy we

Table 2. Significance $(p<.05)$ of Paired-Differences Between the Pharmacy Colleges Website Quality Scores in Different Regions of the World Using a Bonferroni Post-hoc Analysis on the ANOVA Calculated to Compare the Overall Score Mean Difference

\begin{tabular}{|c|c|c|c|c|c|c|c|c|c|}
\hline Central Asia & $\mathrm{S}$ & & & & & & & & \\
\hline Central America & NS & $\mathrm{S}$ & & & & & & & \\
\hline $\begin{array}{l}\text { East \& South East } \\
\text { Asia }\end{array}$ & $\mathrm{S}$ & NS & $\mathrm{S}$ & & & & & & \\
\hline Europe & $\mathrm{S}$ & $\mathrm{S}$ & NS & $\mathrm{S}$ & & & & & \\
\hline Middle East & NS & $\mathrm{S}$ & NS & $\mathrm{S}$ & $\mathrm{S}$ & & & & \\
\hline North America & $\mathrm{S}$ & $\mathrm{S}$ & $\mathrm{S}$ & $\mathrm{S}$ & $\mathrm{S}$ & $\mathrm{S}$ & & & \\
\hline Oceania & $\mathrm{S}$ & $\mathrm{S}$ & $\mathrm{S}$ & $\mathrm{S}$ & $\mathrm{S}$ & $\mathrm{S}$ & NS & & \\
\hline South America & $\mathrm{S}$ & $\mathrm{S}$ & NS & $\mathrm{S}$ & $\mathrm{S}$ & $\mathrm{S}$ & $\mathrm{S}$ & $\mathrm{S}$ & \\
\hline \multirow[t]{2}{*}{ South Asia } & NS & $\mathrm{S}$ & NS & $\mathrm{S}$ & $\mathrm{S}$ & NS & $\mathrm{S}$ & $\mathrm{S}$ & $\mathrm{S}$ \\
\hline & Africa & $\begin{array}{l}\text { Central } \\
\text { Asia }\end{array}$ & $\begin{array}{c}\text { Central } \\
\text { America }\end{array}$ & $\begin{array}{c}\text { East \& South } \\
\text { East Asia }\end{array}$ & Europe & $\begin{array}{l}\text { Middle } \\
\text { East }\end{array}$ & $\begin{array}{c}\text { North } \\
\text { America }\end{array}$ & Oceania & $\begin{array}{c}\text { South } \\
\text { America }\end{array}$ \\
\hline
\end{tabular}

Abbreviations: $\mathrm{S}=$ significant difference, $\mathrm{NS}=$ nonsignificant difference 


\section{American Journal of Pharmaceutical Education 2019; 83 (3) Article 6592.}

Table 3. Association of Socioeconomic Variables with Pharmacy College Website Score

\begin{tabular}{lcc}
\hline Categorical Covariates & Mean (SD) & $\boldsymbol{p}$ value \\
\hline Country member of the G20 & $4.9(3.4)$ & $.016^{*}$ \\
$\quad$ Yes & $4.6(3.2)$ & \\
$\quad$ No & $6.6(3.9)$ & $<.001^{*}$ \\
Country member of the OECD & $4.3(2.8)$ & \\
$\quad$ Yes & Pearson's R & $\boldsymbol{p}$ value \\
No & +0.268 & $<.001$ \\
Integer Covariates & -0.292 & $<.001$ \\
\hline HDI & +0.352 & $<.001$ \\
HDI rank & +0.193 & $<.001$ \\
GNI per capita & & \\
2015-2013 Population with at & +0.269 & $<.001$ \\
$\quad$ least secondary education & +0.156 & $<.001$ \\
Percentage of internet users & & $<.001$ \\
Percentage of mobile phone & -0.216 & \\
$\quad$ users & & .339 \\
Shangai Rank 2015 (non & - & \\
$\quad$ included=1000) & & \\
Number of pharmacists per & & \\
10,000 inhabitants (WHO) & & \\
\hline Abbreviation: G20 Group of Twenty & OED & \\
\hline
\end{tabular}

Abbreviations: $\mathrm{G} 20=$ Group of Twenty, $\mathrm{OECD}=$ Organisation for Economic Co-operation and Development, HDI=Human Development Index, GNI $=$ Gross National Income,

$\mathrm{WHO}=$ World Health Organization

researched failed to provide course syllabi on their website, $24 \%$ included a weak syllabus (document containing just a brief description of course content), and only $3 \%$ included a complete syllabus. According to Noel-Levitz, course content was one of the most important issues for international students. ${ }^{37}$ This information can help students choose the college of pharmacy with the curriculum that best suits their interests. Furthermore, since syllabi include descriptions and course plans, they are an instrument that enhances student learning, assists faculty teaching, increases communication between faculty members about courses, and improves curricular quality. ${ }^{28,38,39}$ Having access to pharmacy college websites with complete information about pharmacy degrees, especially through syllabi, is crucial to ensuring that international students make informed choices. As expected, the websites of colleges in the richest countries (ie, those with the highest socioeconomic variables) scored the highest in our study, suggesting their colleges of pharmacy are better prepared to receive international pharmacy students.

Our study found that the percentage of internet users and the percentage of mobile-phone users in a country had a significant relationship with the scores for pharmacy college websites in the country such that use of these technologies could predict the wealth of the country where the pharmacy colleges were located. To attract international students, it may be important for colleges to ensure that prospective students have as good of an experience using the college's website when accessed on a desktop computer as they do when on a mobile device. ${ }^{18}$ The only socioeconomic variable analyzed that had no significant association with a college's website score was the number of pharmacists per 10,000 inhabitants in the country where the college was located, indicating that the number of pharmacists in their country is not a determining factor for how willing pharmacy colleges are to internationalize.

One potential limitation of our study is that we only evaluated the content of websites written in English, Spanish, French, Portuguese, Italian, or German. However, these six languages are the official or co-official languages in 68 countries with pharmacy colleges that have websites. Thus, our analysis covered a population of more than 3.5 billion people and five of the top 10 languages used on the global internet. ${ }^{40}$ Another possible limitation was that the websites of pharmacy colleges were extracted from the FIP Official World List of Pharmacy Schools, which could not be updated. However, the FIP is the supranational organization in the world of pharmacy and has a specific section on pharmacy education (FIPEd). The scoring system we used did not differentially weight the various elements, which would have required us to use a consensus technique (eg, Delphi). As we only evaluated the content of the websites, our study did not consider the impact of website design or ease-of-use features.

\section{CONCLUSION}

Our study found that a high proportion of pharmacy colleges worldwide still do not have a website, and approximately half of pharmacy college websites do not have an English version of their website. Academic information considered important by students, including syllabi, admission requirements, program costs, and faculty directories, were not available on many of the colleges' websites. There is still much to be done to improve the websites of pharmacy colleges so that they attract international students. Most pharmacy colleges need to update their websites by creating an English version if one is not already available, and to provide the academic information necessary for students to make informed choices about which college of pharmacy offers the curriculum that best serves their interests.

\section{REFERENCES}

1. Cooper C, Burns A. Kohonen self-organizing features maps as a means to benchmark college and university Web sites. J Sci Educ Technol. 2007;16(3):203-211.

2. Noel-Levitz. E-Expectations Report: Focusing your e-recruitment efforts to meet the expectations of college-bound students. 2010. 


\section{American Journal of Pharmaceutical Education 2019; 83 (3) Article 6592.}

https://www.ruffalonl.com/documents/shared/Papers_and_Research/ 2010/E-Expectations_FocusingYour E-RecruitmentEfforts_0710.pdf. Accessed July 25, 2017.

3. Saichaie K, Morphew CC. What college and university websites reveal about the purposes of higher education. J High Educ.

2014;85(4):499-530.

4. Hendricks WM. The influence of the Internet on the choice set of prospective college students during the search and choice stages of the college selection process [PhD thesis]. Widener University, 2006.

5. Simões C, Soares AM. Applying to higher education: information sources and choice factors. Stud High Educ. 2010;35(4):371-89.

6. Noel-Levitz. 2014 E-Expectations Report: The Online Preferences of College-Bound High School Seniors and Their Parents. http://learn. ruffalonl.com/rs/395-EOG-977/images/2014_E-Expectations_Report.pdf. Accessed July 25, 2017.

7. Rahman MS, Ahmed SZ. Exploring the factors influencing the usability of academic websites: a case study in a university setting. Bus Inf Rev. 2013;30(1):40-47.

8. Bernier JL, Barchéin M, Cañas A, Gómez-Valenzuela C, Merelo JJ. The services a university website should offer. http://geneura.ugr. es/ jmerelo/habilitacion2005/papers/63.pdf. Accessed August 24, 2016.

9. Tucciarone KM. Speaking the same language: information college seekers look for on a college website. College \& University Journal. 2009;84(4):22-31.

10. Schimmel K, Motley D, Racic S, Marco G, Eschenfelder M. The importance of university web pages in selecting a higher education institution. Res High Educ J. 2010;9:1-16.

11. Altbach PG, Knight J. The internationalization of higher education: motivations and realities. J Stud Int Educ. 2007;11(3): 290-305.

12. Khan MA, Omrane A, Bank D. The role of internationalization in the higher education industry: an exploratory study. International Journal of Economics \& Strategic Management of Business Process. 2016;7(2):86-99.

13. Hénard F, Diamond L, Roseveare D. Approaches to internationalisation and their implications for strategic management and institutional practice: OECD; 2012.

14. Shields R. Globalization and international student mobility: a network analysis. Comp Educ Rev. 2013;57(4):609-636.

15. Castro P, Woodin J, Lundgren U, Byram M. Student mobility and internationalisation in higher education: perspectives from practitioners. Language and Intercultural Communication. 2016;16(3):418-436.

16. Marmolejo F. Internationalization of higher education: the good, the bad, and the unexpected. the chronicle of higher education. October 22, 2010. http:/www.chronicle.com/blogs/worldwise/ internationalization-of-higher-education-the-good-the-bad-and-theunexpected/27512. Accessed August 24, 2016.

17. Seeber M, Cattaneo M, Huisman J, Paleari S. Why do higher education institutions internationalize? An investigation of the multilevel determinants of internationalization rationales. High Educ. 2016;72(5):685-702.

18. Noel-Levitz. Recruiting Abroad: Understanding the Expectations and Behaviors of Prospective International Students. 2013. http://learn.ruffalonl.com/rs/395-EOG-977/images/2013_ E-Expectations_International.pdf. Accessed July 25, 2017. 19. Noel-Levitz. Meeting the Expectations of International Undergraduate and Graduate Students. 2014. http://learn.ruffalonl.
com/rs/395-EOG-977/images/2014_E-ExpectationsInternational. pdf. Accessed July 25, 2017.

20. Singh A. A comparative analysis of information for international students provided by U.S. and Canadian universities on their websites. [master thesis]. Texas Woman's University; 2013.

21. Owen C, Breheny P, Ingram R, Pfeifle W, Cain J, Ryan M. Factors associated with pharmacy student interest in international study. Am J Pharm Educ. 2013;77(3):Article 54.

22. International Pharmaceutical Federation. Official world list of pharmacy schools. http://academic_institutional_ membership.fip.org/world-list-of-pharmacy-schools/. Accessed January 16, 2014.

23. Buenadicha Mateos M, Chamorro Mera A, Miranda González FJ, González López OR. A new web assessment index: Spanish universities analysis. Internet Res. 2001;11(3):226-234.

24. Herring SC. Web content analysis: Expanding the paradigm. In: Hunsinger J, Klastrup L, Allen M, ed. International handbook of Internet research. Springer; 2009:233-249.

25. Katirci H. Comparison of the content of web sites of higher education institutions providing for sports management education: The case of Turkish and English universities. Educ Res Rev. 2016;11(8):562-572.

26. Shanghai Ranking. Academic Ranking of World Universities 2015. http://www.shanghairanking.com/ARWU2015.html. Accessed July 12, 2016.

27. Central Intelligence Agency. The World FactBook. https://www. cia.gov/library/publications/the-world-factbook/. Accessed February 28, 2014.

28. Johnson C. Best practices in syllabus writing: contents of a learner-centered syllabus. J Chiropr Educ. 2006;20(2):139-144. 29. G20 Members. http://www.oecd.org/g20/g20-members.htm (Archived by WebCite at http://www.webcitation.org/6jsRN7Ukc). Accessed August 19, 2016.

30. Organisation for Economic Co-operation and Development. Members and partners. http://www.oecd.org/about/ membersandpartners/ (Archived by WebCite at http://www. webcitation.org/6jsRQUOat). Accessed August 19, 2016. 31. World Health Organization. Global Health Observatory data repository: Pharmaceutical personnel data by country. http://apps. who.int/gho/data/node.main.HWF3?lang=en. Accessed February 28, 2014.

32. United Nations Development Programme. Human Development Report 2015. http://hdr.undp.org/sites/default/files/2015_human_ development_report.pdf. Accessed July 12, 2016.

33. Egron-Polak E, Hudson R. Internationalization of Higher Education: Growing expectations, fundamental values. IAU 4th global survey. Executive summary: International Association of Universities (IAU); 2014.

34. Meyer KA, Jones S. Information found and not found: what university websites tell students. Online Journal of Distance Learning Administration. 2011;14(3). http://www.westga.edu/ $\sim$ distance/ojdla/fall143/meyer_jones143.html. Accessed August 11, 2016 .

35. Bobo S, Brenn-White M, Montgomery L. Optimizing EnglishLanguage Websites for International Audiences. 2012. http://www. gate-germany.de/fileadmin/dokumente/Marketing_Services/ White_Paper_Website-Check.pdf. Accessed August 11, 2016. 36. Baker W. English as an academic lingua franca and intercultural awareness: student mobility in the transcultural university. Language and Intercultural Communication. 2016;16(3):437-451. 


\section{American Journal of Pharmaceutical Education 2019; 83 (3) Article 6592.}

37. Noel-Levitz. Noel-Levitz Research Report-What Matters to International Students? 2008. https://www.ruffalonl.com/documents/ shared/Papers_and_Research/2008/WhatMattersToInternationalStudents. pdf. Accessed August 24, 2016.

38. Grigorovici D, Nam S, Russill C. The effects of online syllabus interactivity on students' perception of the course and instructor.

Internet High Educ. 2003;6(1):41-52.
39. Peterson SL, Wittstrom KM, Smith MJ. A course assessment process for curricular quality improvement. Am J Pharm Educ. 2011;75(8):Article 157.

40. Internet World Stats. Internet world users by language, Top 10 languages. 2016. http://www.internetworldstats.com/stats7.htm (Archived by WebCite at http://www.webcitation.org/6kIYk829J). Accessed January 16, 2014. 